\title{
Understanding Residents' Support for Tourism Development: The Case of Aqaba City in Jordan
}

\author{
Ibrahim Bazazo ${ }^{1}$, Tariq Elyas ${ }^{2}$, Mahmud Sami Abu Johor ${ }^{1}$, Silliman Fiscal Atmen ${ }^{1} \&$ Abdelrahman Alzwideh ${ }^{3}$ \\ ${ }^{1}$ Department of Tourism Management, Faculty of Tourism and Hospitality, The University of Jordan, Aqaba, Jordan \\ ${ }^{2}$ English Language Institute, King Abdulaziz University, Jeddah, Saudi Arabia \\ ${ }^{3}$ Faculty of Tourism and Hospitality Management, The University of Jordan, Aqaba, Jordan \\ Correspondence: Ibrahim Bazazo, Department of Tourism Management, Faculty of Tourism and Hospitality, The \\ University of Jordan, Aqaba, Jordan. Tel: 962-3-209-0450. E-mail: i.bazazo@ju.edu.jo
}

Received: June 15, 2017

doi: $10.5430 / j m s . v 8 n 3 p 80$
Accepted: June 22, 2017

Online Published: June 27, 2017

\begin{abstract}
This paper aims at investigating the effects of social interaction with tourists, cultural impacts of tourist, welfare impacts of tourism, negative interference of tourism in daily life, economic cost of tourism, sexual permissiveness due to tourism, and perception of crowding on resident support towards sustainable tourism development. A total of 568 questionnaire containing 34 items was used to collect information from the local residents in Aqaba city. Multiple regression analysis was conducted to test the research hypotheses. Results of the current study revealed that there are significant impacts of six independent variables (i.e. social interaction with tourists, cultural impacts of tourist, welfare impacts of tourism, less negativeness towards interference of tourism in daily life, less economic cost of tourism, and less sexual permissiveness due to tourism) on support for sustainable tourism development; whereas crowding on resident support has not significant impact on it. Results of T-test showed that there is a significant difference in the impact of resident attitudes towards sustainable tourism development in favor of gender. On the other hand, results of ANOVA test found that there is significant difference in the impact of resident attitudes towards sustainable tourism development that can be attributed to age and educational level; whereas no significant difference in favor of personal income.
\end{abstract}

Keywords: tourism development, Aqaba, Jordan, tourism awareness, sustainable tourism

\section{Introduction}

Tourism is a provision of facilities and services to satisfy the needs and desires of tourists, and also includes some of the impacts of tourism, such as: creating new jobs and new entry, the development of tourism in the expansion and upgrading of tourist services and needs, and require the intervention of the tourism development of tourism planning as a scientific approach aimed at achieving the maximum rate of the lowest possible cost growth in tourism and as soon as possible. The growing interest in tourism as a rural economic development tool poses a variety of challenging issues and questions to those concerned with revitalization of the nation' smaller communities (Lapp, 2008). The tourism development often seeks to achieve a balance between economic diversification and preservation of the life style qualities sought by many rural residents while enhancing the range of choices available to them (Field, 1986). The overall purpose of tourism development should be to enhance the quality of resident's lives by addressing the economic, social, cultural, recreational, and other benefits of tourism (Cottrell et al., 2013; Masa'deh, 2016).

Also, economic policies cannot alone define the results to the problems of tourism development, but you need to clarify the political structure and personal interests in order to reduce the Anger at the economic factor (Tosun, 2000). The main objective of this study is to reduce the restrictions on tourism development and working on the practical application of hydration tourism and community participation to develop the decision-making process. The lifestyle of the communities residents may influence the structural changes within the tourism industry occurring as a result of the ongoing development of tourism, such as changes in the local (Maynard \& Jones, 2007). The society, which is planned uses tourism as an alternative means of promoting economic development must develop it to meet the needs and demands of its population (Puck \& Rats, 2000); and understanding the precedents of support by local residents for tourism development can help to promote sustainable tourism because communities can assess these precedents to 
predict the level of support by their residents (Lai \& Nepal, 2006). Factors that have been shown to affect the perceptions and attitudes of the population and include the type and extent of the guest host interaction, is the importance of the industry to the community and how individuals rely on the industry, the overall level of tourism development in the community (Zhang et al., 2006).

Aqaba suffers from several problems hindering the development of which the process of the great congestion and economic high cost and negative interference of tourism in life society so we do this research to understand and grasp these problems and work to resolve them to provide effective advice to the competent authorities of the public and private sectors. Therefore, this study aims to identify the extent of support for the development of sustainable tourism in the city of Aqaba, identify the cultural relics to tourists, identify the tourism awareness among the local community in the city of Aqaba, identify the degree of congestion resulting from tourism in the city of Aqaba output, identify the level of community interaction with tourists in the city of Aqaba, and to identify the capacity of the tourist sites in the city. Indeed, the importance of the study triggers as the tourism awareness is the main pillar in the development of the local community for the tourist city of Aqaba; and noticing that absorptive capacity is considered an essential element in the development of tourist site in the city of Aqaba; and that control over financial cost in tourist operation is one of the fundamentals of development in the city of Aqaba; and thus determining the level of community satisfaction for the development of tourism projects in the city of Aqaba. Furthermore, the reasons for the study identifies to show the city of Aqaba as the head of the Golden Triangle in Jordan and Tourism sector regarded as a source of national income which contributes well in Jordan, and tourism is the backbone of the economies in boosting tourism in the city of Aqaba.

\section{Literature Review}

\subsection{Residents' Attitudes towards Tourism Impacts}

This study is based on the study of the positive effects of tourism to the population in the city of Shiraz / Iran, the present study indicate the existence of a close link between the tourism impact, and residents and according to the results found that the positive results are related to social, cultural relics dramatically when it was found that environmental factors, economic It is the least impact. The test analysis of the study indicates that there is no significant difference between the leaders' attitudes in both districts of Shiraz. Results drawn from focus group discussion with the local residents also show that the residents have positive attitudes toward tourism impacts on their communities (Fariborz, 2010).

\subsection{Understanding Community Attitudes towards Tourism and Host-Guest}

This study is based on a better understanding of both the local community about the concepts of tourism and host interaction with the guest, and this study discusses research gaps glaring through a literature review and provide appropriate solutions in the study area and also this study is concerned with the ethnic toll, community towards tourism and shows this study of the urgent need to develop a solid theoretical framework for understanding and predicting the interaction of the host and the guest has resulted in the number of outputs, a study of the heterogeneity of the population of the community makes it complex to understand the different attitudes towards tourism in the community. Researchers from disciplines variation, and also found many of the demographic and psychological factors are often influential on society's attitudes towards tourism, such as sex, age and life cycle, and participation in the tourism industry, adding finally all these in our understanding of community attitudes toward tourism complex (Zhang et al., 2006).

\subsection{Influence Analysis of Community Resident Support for Sustainable Tourism Development}

This study in southwestern Taiwan, this study aims to assess the support of the residents of the community for the development of sustainable tourism by using the latent variables facility, community, and community involvement, the expected benefits and costs perceived, and to provide support for the development of sustainable tourism, and indicate the analytical results relating to community participation community that the important factors that affect the level of support for the development of tourism. Have a positive impact on the relationship between the facility and the community to provide support for the development of sustainable tourism and the community involvement and support for sustainable tourism development (Lee, 2013).

\subsection{A Structural Equation Model of Residents' Attitudes for Tourism Development}

This study was conducted in Jeju / Korean Peninsula and are based on testing structural equation between the impacts of tourism which is seen as the population toward the guest or Sayeh model has been shown that "the community has a high level of satisfaction and was closely related to the positive effects and these combinations are directly causing create a look holistic attitudes toward pertaining to tourism development, but the track that were "personal benefits has 
rejected this development and at the conclusion of this study the researcher added words: You may realize community satisfaction through the realization of Antiquities and Tourism, and can be helpful in planning for tourism development (Wanko \& Stewart, 2002).

\subsection{Residents' Perceptions of Community Tourism Impact}

This study is to investigate the perceptions of the population towards the development of tourism and its effects, data were collected through a survey, using social exchange theory. The results indicate that many residents recognize the positive and negative results. They are those who feel that tourism is an important component of economic development, and they are aware that the positive effects of larger, but no different from the others with respect to perceptions of negative tours, has Acharo researchers in the study, said awareness campaigns for tourism could be a step to understand the industry (Andereck et al., 2005).

\subsection{Resident Attitudes: A Structural Modeling Approach}

The objective of this research is to model host community support for tourism development based on the factors found to influence reactions towards it. Using the literature, a tourism support model with hypotheses involving several paths was proposed. Data were collected from five counties surrounding a Virginia (USA) recreation area, and the model and hypothesized paths were tested. The lisrel-8 structural equation analysis package was utilized with maximum likelihood method of estimation in combination with the two-stage process. The findings revealed that the host community support is affected by the level of concern, ecocentric values, utilization of resource base, perceived costs and benefits of the tourism development (Gursoy et al., 2002).

\subsection{A Cross-Cultural Analysis of Tourism and Quality of Life Perceptions}

Models of sustainable tourism consider not only the aspects of the physical environment but also the dimensions of the social and cultural environment of destinations. During the past two decades a number of researchers have made the case that local residents must be involved in tourism development decisions if support for, and thereby sustainability of, the industry is to be maintained. Minority ethnic and racial groups, however, are often differentially influenced by tourism within a community. This study investigates the differences between Hispanic and Anglo residents with respect to their perceptions of tourism and quality of life framed with the context of ethnicity marginality theory (Andereck et al., 2005).

\subsection{Residents' Attitudes toward Existing and Future Tourism Development in Rural Communities}

Building on the model by Perdue, Long, and Allen, this study examined residents' attitudes toward existing and future tourism development in several rural areas at different stages of tourism and economic development. Social exchange theory and destination life cycle model were used to examine the impacts of tourism development on residents' attitudes when considered in conjunction with a community's total economic activity. New social predictors and endogenous factors were tested in the model. Overall, residents of three distinct rural county-level areas were supportive of tourism development, and little evidence was found that suggests that attitudes toward tourism become negative with higher levels of tourism. After considering the level of tourism development in conjunction with the total economic activity, residents of the three county-level areas showed some signs of destination life cycle influencing their own relationship with tourism (Latkova \& Vogt, 2012).

\subsection{Measuring Residents' Attitude toward Sustainable Tourism}

The purpose of this study is to develop and validate a scale assessing residents' attitudes toward sustainable tourism (SUSTAS). Following the pretesting phase, a 51-item scale of resident attitudes toward sustainable community tourism was administered to 800 households in a small tourism community in Texas. Psychometric properties of SUSTAS along with its practical and theoretical implications are discussed within the framework of sustainable tourism development (Choi \& Sirakaya, 2005).

\subsection{Tourism Use History: Exploring a New Framework for Understanding Residents' Attitudes toward Tourism}

This study attempts to answer the question "What influence does an individual's travel have on attitudes concerning who should develop tourism in their community as well as the role of the government in such development?" Research on residents' attitudes toward tourism has traditionally focused on demographic, socioeconomic, and spatial predictor variables, with relatively few consistent findings. Based on the experience use history concept from the leisure and outdoor recreation literature, this study explores a new framework for understanding residents' attitudes toward tourism in two distinct destinations in South Carolina, United States. Tourism use history was used to create resident groups within each community and assess attitudes about who should develop tourism (e.g., local businesses, outside investors and developers, government, or a public-private partnership) and government support 
for tourism businesses. Results are discussed in relation to the stage of tourism development in each destination. Further development and testing of tourism use history is recommended (Draper et al., 2011)

\subsection{Residents' Attitudes toward Tourism and Perceived Personal Benefits in a Rural Community}

This research focuses on residents' perceptions of personal benefits from tourism, identifying not only the relationships between personal benefits from tourism and residents' attitudes toward tourism but also the nature of benefits associated with tourism. The study was conducted in a small rural community where tourism is still at its emerging stage. It was found that residents' perceptions of personal benefits from tourism were closely associated with their attitudes toward tourism in a positive direction. The significant contribution of this study falls on the recognition of noneconomic perspective of tourism benefits for residents in a community where tourism has not yet explicitly emerged. In particular, the data lend support for social exchange theory and improve its understanding in tourism investigations (Wang \& Pfister, 2008).

\subsection{Resident Satisfaction with Sustainable Tourism}

This article examined the relative influence of four sustainability dimensions (i.e., environmental, economic, socio-cultural, and institutional) in predicting resident satisfaction with sustainable tourism development. Data were collected from residents near Frankenwald Nature Park (FNP) in Germany $(n=306)$. The dimensions were based on three to eight survey items. Perceived satisfaction was a five-item measure of resident satisfaction. Structural equation modeling supported the hypothesis that all four dimensions were significant predictors of satisfaction. The economic dimension was the strongest predictor, followed by the institutional, social, and environmental dimensions. Findings indicate that all four dimensions should be included for a holistic approach to planning and monitoring sustainable tourism development. Future research opportunities include improving the measurement of sustainability indicators and developing standards associated with each indicator (Cottrell et al., 2013).

\subsection{Objective Indicators of the Impact of Rural Tourism Development}

Over the past decade, many rural communities have been encouraged to incorporate tourism in their economic development strategies. Tourism is increasingly seen as a potential basic industry providing employment opportunities, income and economic diversity. However, concerns over the potential impacts have created a demand for comprehensive planning and research on the effects of tourism development on residents' quality of life. The purpose of this study was to demonstrate an objective means of determining the impact tourism development has on rural residents' quality of life. Using census data from rural counties in a US state, the findings suggest that tourism development is a viable means of improving the quality of life in rural communities. However, as in the case of any economic development alternatives, there are a number of underlying consequences that should be anticipated and planned for in pursuing a tourism development strategy that is appropriate and sustainable (Crotts \& Holland, 2013).

\subsection{Challenges of Sustainable Tourism Development in the Developing World}

This article presents an analysis of the challenges to sustainable tourism development in developing countries with special references to Turkey as a part of the developing world. It was found that the factors that have emerged as challenges to sustainable tourism development related to priorities of national economic policy, the structure of public administration, an emergence of environmental issues, over commercialization, and the structure of international tourism system. It concludes that although the principles of sustainable tourism development are beneficial, their implementation is an enormously difficult task to achieve and owing to the prevailing socio-economic, technological and political conditions in the developing world. Hence, any operation of principles of sustainable tourism development necessitates hard political and economic choices, and decisions based upon complex socio-economic and environmental trade-offs. Moreover, it states that implementation of these hard decisions may not be possible unless international organizations encourage and collaborate with governments of developing countries to implement the principles of sustainable tourism development (Tosun, 2000). Indeed, several researchers consider the information systems and in particular the information technology (IT) and its flexibility as an enabler to achieve the desired competitive advantages, and as a crucial support to operational and strategic business decisions (Al Azmi et al., 2012; Alenezi et al., 2015; Alkalha et al., 2012; Almajali \& Tarhini, 2016; Altamony et al., 2012; Kateb et al., 2015; Maqableh \& Karajeh, 2014a, 2014b; Masa'deh, 2012, 2013a, 2013b; Masa'deh et al., 2016; Obeidat et al., 2013; Shannak, et al. 2010, 2012a, 2012b; Tarhini et al., 2016; Vratskikh et al., 2016); thus further research is required to examine the role of such IT applications in enhancing the managerial decisions. In addition, scholars (e.g. Masa'deh et al. 2008; Hunaiti et al., 2009; Masa'deh \& Kuk, 2009; Alshurideh et al., 2012; Hajir et al., 2015; Kannan \& Gharibeh, 2013; Masa'deh \& Shannak, 2012; Masa'deh et al. 2013; Masa'deh et al. 2015a, 2015b, 2015c; Masa'deh et al. 2017; Obeidat et al., 2012, 2016; Shannak \& Alkour, 2012; Tarhini et al., 
2015a, 2015b) emphasize the need for large firms to integrate their IT systems with their KM strategies and processes in order to survive in their highly competitive business environments, which in turn could accelerate the managerial decisions as well.

\section{Research Methodology}

This section provides the methodology applied in the current study. It consists of the research model, operational definitions of the study's independent and dependent variables, research hypotheses, besides data collection tool and research population and sample.

\subsection{Research Model}

The elements of this research are established based on preceding literature, either theoretically or empirically. Indeed, this study used variables that are common in tourism development literature. Figure (1) represents a model for the study that shows the independent variables, the dependent variable (support for sustainable tourism development), and the proposed relationship between them.

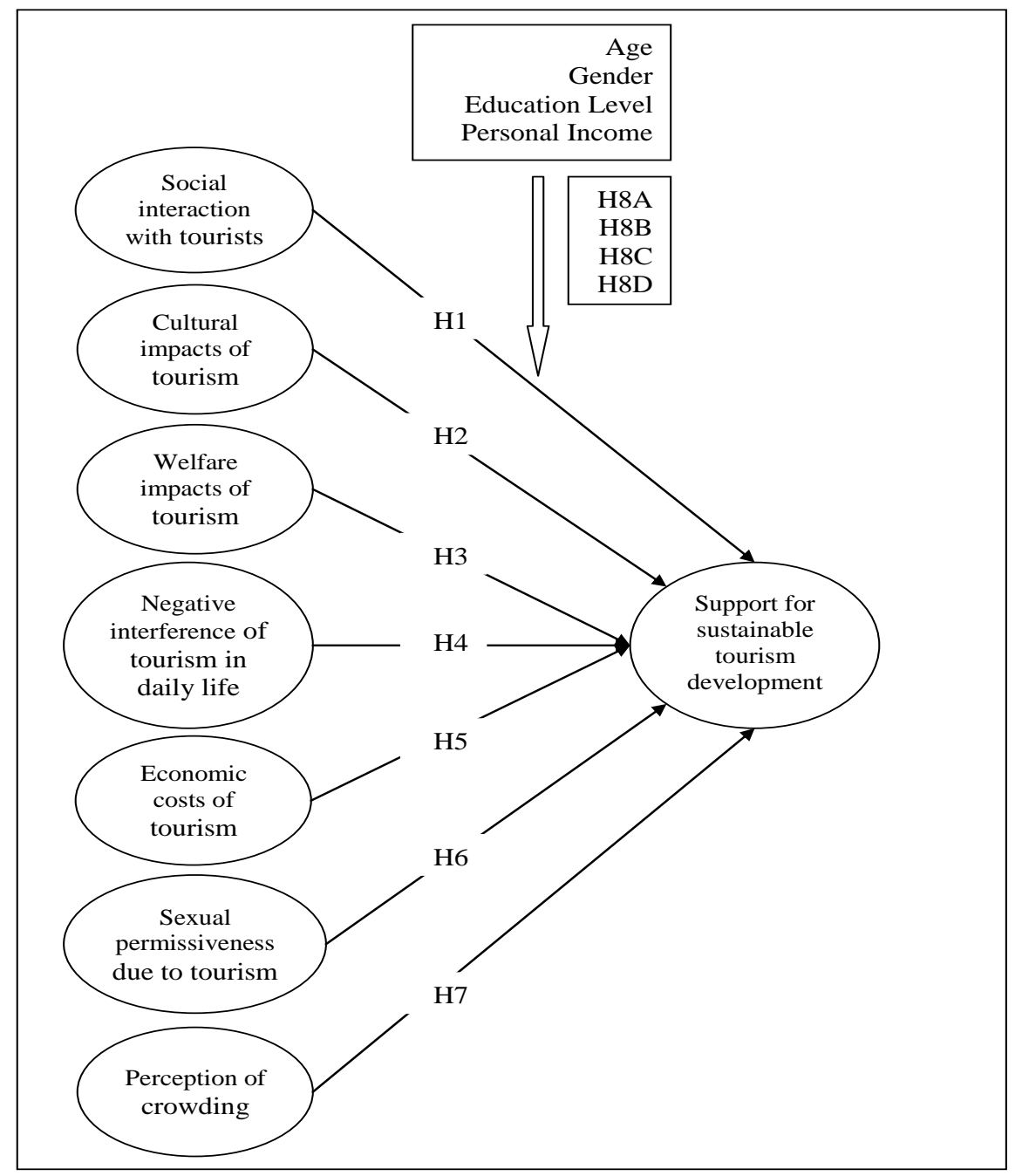

Figure 1. Research Model

\subsection{Operational Definitions}

Adapted from Sirakaya et al. (2002), the current research considers seven independent variables within the construct of resident support towards sustainable tourism development (the dependent variable which is adapted from (Lee, 2013); and measured through five items). Further, the determinants of support for tourism development includes 
social interaction with tourists, cultural impacts of tourist, welfare impacts of tourism, negative interference of tourism in daily life, economic cost of tourism, sexual permissiveness due to tourism, and perception of crowding; which were measured in the research questionnaire through five, six, five, five, three, two, and three items respectively.

\subsection{Research Hypotheses}

In order to test the research model of the impact of resident attitudes towards sustainable tourism development, the study is hypothesized as follows:

H1: There is a statistically significant impact of social interaction with tourists on support for sustainable tourism development.

$\mathrm{H} 2$ : There is a statistically significant impact of cultural impacts of tourist on support for sustainable tourism development.

H3: There is a statistically significant impact of welfare impacts of tourism on support for sustainable tourism development.

H4: The less negativeness of interference of tourism in daily life affects residents' support for sustainable tourism development.

H5: The less economic cost of tourism affects residents' support for sustainable tourism development.

H6: The less sexual permissiveness due to tourism affects residents' support for sustainable tourism development.

H7: There is a statistically significant impact of perception of crowding on support for sustainable tourism development.

H8A: There is a significant difference in the impact of resident attitudes towards sustainable tourism development due to gender.

H8B: There is a significant difference in the impact of resident attitudes towards sustainable tourism development due to age.

H8C: There is a significant difference in the impact of resident attitudes towards sustainable tourism development due to educational level.

H8D: There is a significant difference in the impact of resident attitudes towards sustainable tourism development due to personal income.

\subsection{Population and Sampling}

The study population consisted of all spectrums of the community interested in tourism in Aqaba city includes all age levels (from 18 to 40 years and above). 1000 questionnaires were distributed and considered 600 of them for statistical analysis, thus the response rate was $60 \%$ which is high for the community of the city of Aqaba.

\section{Data Analysis and Results}

In order to explore the impact of resident attitudes towards sustainable tourism development, in which these variables have been measured using 5-points Likert scale that varies between not agree at all $=1$ and totally agree $=5$; except negativeness of interference of tourism in daily life, economic cost of tourism, and sexual permissiveness due to tourism were reversed. Also, reliability and validity analyses were conducted; descriptive analysis was used to describe the characteristic of sample and the respondent to the questionnaires besides the independent and dependent variables. Also, multiple regression analysis was employed to test the research hypotheses.

\subsection{Validity and Reliability}

Validity and reliability are two important measures to determine the quality and usefulness of the primary data. Validity is about accuracy and whether the instrument measures what it is intended to measure while reliability is about precision; it is used to check the consistency and stability of the questionnaire. Indeed, the researchers depended on scales and items that were previously developed and used by other researchers with similar interest. Also a draft of the questionnaire was formulated, and then it was reviewed by five academic lecturers -who have a sufficient knowledge and experience in this scope- to insure that each item is measuring what is intended to be measured, and to avoid the ambiguity and complexity in the phrasing of questions. The reliability of the instrument was measured by the Cronbach's alpha coefficient. Further, some scholars (e.g. Bagozzi \& Yi, 1988) suggested that the values of all indicators or dimensional scales should be above the recommended value of 0.60 . Table (1) represents the results of Cranach's alpha for the independent and dependent variables. Cronbach's alpha coefficients 
of all the tested variables are above 0.60 which suggesting the composite measure is reliable.

Table 1. The Cronbach's alpha coefficients of study variables

\begin{tabular}{lcc}
\hline Variables & Number of items & Cronbach alpha \\
\hline Social interaction with tourists & 5 & 0.873 \\
\hline Cultural impacts of tourist & 6 & 0.916 \\
\hline Welfare impacts of tourism & 5 & 0.860 \\
\hline Negative interference of tourism in daily life (Reversed) & 5 & 0.813 \\
\hline Economic cost of tourism (Reversed) & 3 & 0.754 \\
\hline Sexual permissiveness due to tourism (Reversed) & 2 & 0.740 \\
\hline Perception of crowding & 3 & 0.798 \\
\hline Support for sustainable tourism development & 5 & 0.936 \\
\hline
\end{tabular}

\subsection{Respondents Demographic Profile}

As indicated in Table 2, the demographic profile of the respondents for this study showed that they are typically males, most of them between 18-30 years old, the majorities hold bachelor degrees; and most of them earn less than 1000 JD (i.e. $1500 \$$ monthly).

Table 2. Description of the respondents' demographic profiles

\begin{tabular}{|c|c|c|c|}
\hline Category & Category & Frequency & Percentage\% \\
\hline \multirow[t]{3}{*}{ Gender } & Males & 331 & 58.3 \\
\hline & Females & 237 & 41.7 \\
\hline & Total & 568 & 100 \\
\hline \multirow[t]{5}{*}{ Age } & 18 years - less than 25 & 372 & 65.4 \\
\hline & 25 years - less than 30 & 114 & 20.1 \\
\hline & 30 years - less than 40 & 68 & 12.0 \\
\hline & More than 40 years old & 14 & 2.5 \\
\hline & Total & 568 & 100 \\
\hline \multirow[t]{7}{*}{ Education level } & Less than Tawjehi & 18 & 3.2 \\
\hline & Tawjehi & 40 & 7.0 \\
\hline & Diploma & 60 & 10.6 \\
\hline & Bachelor & 404 & 71.1 \\
\hline & Master & 41 & 7.2 \\
\hline & Doctorate & 5 & 0.9 \\
\hline & Total & 568 & 100 \\
\hline \multirow{4}{*}{$\begin{array}{l}\text { Personal income (JD) } \\
\text { monthly }\end{array}$} & Less than 500 & 236 & 41.5 \\
\hline & 500- less than 1000 & 223 & 39.3 \\
\hline & More than 1000 & 109 & 19.2 \\
\hline & Total & 568 & 100 \\
\hline
\end{tabular}

\subsection{Descriptive Analysis}

In order to describe the responses and thus the attitude of the respondents toward each question they were asked in the survey, the mean and the standard deviation were estimated. While the mean shows the central tendency of the data, the standard deviation measures the dispersion which offers an index of the spread or variability in the data (Sekaran \& Bougie, 2013). In other words, a small standard deviation for a set of values reveals that these values are 
clustered closely about the mean or located close to it; a large standard deviation indicates the opposite. The level of each item was determined by the following formula: (highest point in Likert scale - lowest point in Likert scale) / the number of the levels used $=(5-1) / 5=0.80$, where 1-1.80 reflected by "very low", 1.81-2.60 reflected by "low", 2.61-3.40 reflected by "moderate", 3.41-4.20 reflected by "high", and 4.21-5 reflected by "very high". Then the items were being ordered based on their means. Tables 3 and 4 show the results.

Table 3. Overall mean and standard deviation of the study's variables

\begin{tabular}{clcccc}
\hline $\begin{array}{c}\text { Type of } \\
\text { Variable }\end{array}$ & Variables & Mean & $\begin{array}{c}\text { Standard } \\
\text { Deviation }\end{array}$ & Level & Order \\
\hline $\begin{array}{c}\text { Independent } \\
\text { Variables }\end{array}$ & Social interaction with tourists & 3.50 & 1.01 & High & 4 \\
\hline & Cultural impacts of tourist & 3.56 & 1.04 & High & 3 \\
\hline & Welfare impacts of tourism & 3.59 & 0.95 & High & 2 \\
\hline & $\begin{array}{l}\text { Negative interference of tourism in daily life } \\
\text { (Reversed) }\end{array}$ & 2.74 & 1.03 & $\begin{array}{c}\text { Moderat } \\
\text { e }\end{array}$ & 7 \\
\hline & Economic cost of tourism (Reversed) & 2.41 & 1.02 & Low & 5 \\
\hline & $\begin{array}{l}\text { Sexual permissiveness due to tourism } \\
\text { (Reversed) }\end{array}$ & 2.33 & 1.08 & Low & 6 \\
\hline & Perception of crowding & 3.64 & 1.02 & High & 1 \\
\hline $\begin{array}{c}\text { Dependent } \\
\text { Variable }\end{array}$ & Support for sustainable tourism development & 3.68 & 1.20 & High & \\
\hline
\end{tabular}

As presented in Table 3, data analysis results have shown that residents' support for sustainable tourism development in Aqaba is applied to a high level in which the mean score is 3.68. Also, perception of crowding, welfare impacts of tourism, cultural impacts of tourist, social interaction with tourists, and economic cost of tourism do exist highly and respectively; whereas both variables of sexual permissiveness due to tourism and negative interference of tourism in daily life are applied to a less extent in Aqaba city. Table 4 demonstrates the mean, standard deviations, level, and order scores for resident attitudes towards sustainable tourism development items for each variable.

Table 4. Mean and standard deviation of the study's variables

\begin{tabular}{lcccc}
\hline Social interaction with tourists & Mean & SD & Level & Order \\
\hline I have developed friendships with tourists & 3.46 & 1.25 & High & 4 \\
\hline My interactions with tourists are positive and useful & 3.42 & 1.22 & High & 5 \\
\hline I enjoy interacting with tourists & 3.47 & 1.24 & High & 3 \\
\hline I now enjoy visiting tourist areas & 3.59 & 1.26 & High & 1 \\
\hline I like learning about tourists' own country and culture & 3.58 & 1.22 & High & 2 \\
\hline Cultural impacts of tourist & Mean & SD & Level & Order \\
\hline Tourism promotes cultural exchange & 3.64 & 1.30 & High & 2 \\
\hline The jobs tourism provides are highly desirable & 3.59 & 1.26 & High & 4 \\
\hline Tourism promotes better understanding between people & 3.64 & 1.21 & High & 2 \\
\hline $\begin{array}{l}\text { Tourism helps to increase local awareness and appreciation of the } \\
\text { environment }\end{array}$ & 3.66 & 1.25 & High & 1 \\
\hline Tourism helps to preserve and improve our culture and traditions & 3.23 & 1.23 & Moderate & 5 \\
\hline Because of tourism development, I have a better appreciation of my culture & 3.62 & 1.19 & High & 3 \\
\hline Welfare impacts of tourism & Mean & SD & Level & Order \\
\hline Tourism improves public utilities (water, electricity, telephone, tourism, & 3.62 & 1.21 & High & 3 \\
\hline
\end{tabular}


etc.) in our community

\begin{tabular}{|c|c|c|c|c|}
\hline Because of tourism, Aqaba city has better roads & 3.64 & 1.20 & High & 2 \\
\hline $\begin{array}{l}\text { The quality of public services (roads, water, sewage, etc.) in Aqaba city is } \\
\text { better due to more tourism }\end{array}$ & 3.67 & 1.17 & High & 1 \\
\hline Aqaba city has lost its small-town atmosphere because of tourism & 3.58 & 1.25 & High & 4 \\
\hline Tourism improves transportation services in our community & 3.48 & 1.21 & High & 5 \\
\hline Negative interference of tourism in daily life (Reversed) & Mean & SD & Level & Order \\
\hline Tourism development in Aqaba city has caused me to regret living here & 2.93 & 1.40 & Moderate & 4 \\
\hline $\begin{array}{l}\text { Because of tourism, I have more difficulty participating in entertainment } \\
\text { events }\end{array}$ & 2.98 & 1.41 & Moderate & 5 \\
\hline Tourists interfere with my enjoyment of this town & 2.51 & 1.33 & Low & 1 \\
\hline Most people I know don't like tourism & 2.60 & 1.33 & Low & 2 \\
\hline $\begin{array}{l}\text { I am against new tourism facilities, which will attract more tourists to } \\
\text { Aqaba city }\end{array}$ & 2.72 & 1.37 & Moderate & 3 \\
\hline Economic cost of tourism (Reversed) & Mean & SD & Level & Order \\
\hline Tourism only benefits a few people in Aqaba city & 2.33 & 1.25 & Low & 1 \\
\hline Tourism increases the cost of living & 2.52 & 1.21 & Low & 3 \\
\hline Tourists should pay more than local residents to visit tourist attractions & 2.40 & 1.24 & Low & 2 \\
\hline Sexual permissiveness due to tourism (Reversed) & Mean & SD & Level & Order \\
\hline Tourism increases prostitution in Aqaba city & 2.34 & 1.20 & Low & 2 \\
\hline Tourism increases sexual permissiveness in Aqaba city & 2.33 & 1.23 & Low & 1 \\
\hline Perception of crowding & Mean & SD & Level & Order \\
\hline Tourists cause my town to be crowded with people & 3.64 & 1.22 & High & 2 \\
\hline Recreation areas in Aqaba city are overcrowded because of tourism & 3.63 & 1.18 & High & 3 \\
\hline The tourism sector provides a ready market for the product of local citizens & 3.67 & 1.23 & High & 1 \\
\hline Support for sustainable tourism development & Mean & SD & Level & Order \\
\hline $\begin{array}{l}\text { I support the development of community-based sustainable tourism } \\
\text { initiatives }\end{array}$ & 3.57 & 1.51 & High & 5 \\
\hline I participate in sustainable tourism-related plans and development & 3.61 & 1.35 & High & 4 \\
\hline I participate in cultural exchanges between local residents and visitors & 3.70 & 1.30 & High & 3 \\
\hline I cooperate with tourism planning and development initiatives & 3.74 & 1.29 & High & 2 \\
\hline I participate in the promotion of environmental education and conservation & 3.79 & 1.30 & High & 1 \\
\hline
\end{tabular}

\subsection{Hypotheses Testing Results}

The current research is mainly seeking to investigate the impact of resident attitudes towards sustainable tourism development in Aqaba city in Jordan. Consequently, in order to test the hypotheses developed for this study, multiple regression technique was used. Further, the level of significance ( $\alpha$-level) was chosen to be 0.05 and the probability value (p-value) obtained from the statistical hypotheses test is considered to be the decision rule for rejecting the null hypotheses (Creswell, 2009). If the p-value is less than or equal to $\alpha$ - level, the null hypothesis will be rejected and the alternative hypothesis will be supported. However, if the p-value is greater than the $\alpha$-level, the null hypothesis cannot be rejected and the alternative hypothesis will not be supported. In addition, normality of the independent variables and the absence of multi co-linearity problem (a case of multiple regression in which the independent variables are themselves highly correlated) were checked. According to Pallant (2005), most of the values should be inside the adequate ranges for normality (i.e. -1.0 to +1.0 ). For this purpose, skewness and Variance Inflation Factor (VIF) were investigated; Table 5 includes the results. 
Table 5. Skewness and VIF for the independent variables

\begin{tabular}{lccc}
\hline Variables & Tolerance & VIF & Skewness \\
\hline Social interaction with tourists & 0.555 & 1.802 & 0.747 \\
\hline Cultural impacts of tourist & 0.510 & 1.959 & 0.787 \\
\hline Welfare impacts of tourism & 0.527 & 1.896 & 0.845 \\
\hline Negative interference of tourism in daily life & 0.700 & 1.429 & 0.780 \\
\hline Economic cost of tourism & 0.473 & 2.116 & 0.417 \\
\hline Sexual permissiveness due to tourism & 0.553 & 1.807 & 0.299 \\
\hline Perception of crowding & 0.475 & 2.107 & 0.823 \\
\hline
\end{tabular}

As can be noticed from Table 5, the skewness values were within the normal values $(-1.0$ to +1.0$)$ suggesting that the data of the independent variables is normal. The VIF values were less than the critical value (10) which is most common among the most studies, suggesting no multi co-linearity problem among the independent variables. However, the results of testing the seven hypotheses on the impact of resident support towards sustainable tourism development are demonstrated in Table 6.

Table 6. Result for the study model (b)

\begin{tabular}{llllllll}
\hline Variable & $\mathbf{r}$ & $\mathbf{R}^{2}$ & $\mathbf{f}$ & $\mathbf{S i g}(\mathbf{f})$ & $\boldsymbol{\beta}$ & $\mathbf{t}$ & Sig (t) \\
\hline Social interaction with tourists & 0.780 & 0.608 & 124.175 & $0.000 \mathrm{a}$ & 0.138 & 3.234 & 0.001 \\
Cultural impacts of tourist & & & & & 0.570 & 15.390 & 0.000 \\
Welfare impacts of tourism & & & & & 0.125 & 3.419 & 0.001 \\
Negative interference of tourism in daily life & & & & & 0.103 & 1.975 & 0.050 \\
Economic cost of tourism & & & & & 0.111 & 2.422 & 0.016 \\
Sexual permissiveness due to tourism & & & & & 0.106 & 1.962 & 0.050 \\
Perception of crowding & & & & & 0.004 & 0.106 & 0.915 \\
\hline
\end{tabular}

a. Predictors: (Constant), Social interaction with tourists, Cultural impacts of tourist, Welfare impacts of tourism, Negative interference of tourism in daily life, Economic cost of tourism, Sexual permissiveness due to tourism, Perception of crowding

b. Dependent variable: Support for sustainable tourism development

Refer to Table 6 the multiple correlation coefficient $R=0.780$ indicates that there is a strong positive correlation between the independent variables (social interaction with tourists, cultural impacts of tourist, welfare impacts of tourism, negative interference of tourism in daily life, economic cost of tourism, sexual permissiveness due to tourism, and perception of crowding) support for sustainable tourism development. The $\mathrm{R}^{2}$ indicated the generalizability of the model. It allows us to generalize the results taken from the respondents to the whole population. In this case it equals 0.608 . The results showed that F-ratio for these data is equal to 124.175 , which is statistically significant at $\mathrm{p}<0.05$. Therefore, we conclude that there is a statistically significant impact of the independent variables on residents' support for sustainable tourism development.

The $\beta$ indicates the individual contribution of each predictor (independent variable) to the model, if other predictors are held constant. Table 6 shows the standardized coefficients for each independent variable. The value of $\beta$ for social interaction with tourists, cultural impacts of tourist, welfare impacts of tourism, negative interference of tourism in daily life, economic cost of tourism, and sexual permissiveness due to tourism are $0.138,0.570,0.125$, $0.103,0.111$, and 0.106 respectively, which are positive. While for perception of crowding; the value of $\beta$ is 0.004 , which have small values compared with other predictors. The level of effect of these variables depends on the $\beta$ value, the higher $\beta$ value the higher effect on dependent variable. We can infer from the values of beta that the variable that has the highest contribution in the model is cultural impacts of tourist, followed by welfare impacts of tourism, less economic cost of tourism, less negative interference of tourism in daily life respectively, and less sexual permissiveness due to tourism. 
Hypotheses H8A, H8B, H8C, and H8D argued that there is a significant difference in the impact of resident attitudes towards sustainable tourism development due to gender, age, educational level, and personal income. Independent Samples T-test was employed in order to investigate if there any significant differences in the impact resident attitudes towards sustainable tourism development that can be attributed to gender. Also, ANOVA test was employed to examine if there any significant differences in the impact of resident attitudes towards sustainable tourism development that can be attributed to age, educational level, and personal income. Results of T-test, shown in Table 7 , indicated that there is a significant difference in the impact of resident attitudes towards sustainable tourism development that can be attributed to gender. However, results of ANOVA test, shown in Table 8 and Table 9 indicated that there is significant difference in the impact of resident attitudes towards sustainable tourism development in favor of age and educational level; whereas no significant difference in favor of personal income, see Table 10.

Table 7. T-test of resident attitudes towards sustainable tourism development due to gender

\begin{tabular}{|c|c|c|c|c|c|c|c|c|c|}
\hline \multirow[b]{2}{*}{ Variables } & \multicolumn{3}{|c|}{ Male } & \multicolumn{3}{|c|}{ Female } & \multirow{2}{*}{$\mathbf{T}$} & \multirow{2}{*}{ df } & \multirow{2}{*}{ Sig. } \\
\hline & $\mathbf{N}$ & Mean & Std. Dev. & $\mathbf{N}$ & Mean & Std. Dev. & & & \\
\hline $\begin{array}{l}\text { Support for } \\
\text { sustainable tourism } \\
\text { development }\end{array}$ & 237 & 3.4160 & 1.38573 & 331 & 3.8743 & 1.02616 & 4.314 & 412.257 & 0.000 \\
\hline
\end{tabular}

Table 8. ANOVA Analysis of resident attitudes towards sustainable tourism development due to age

\begin{tabular}{ccccccc}
\hline Variables & \multicolumn{2}{c}{$\begin{array}{c}\text { Sum of } \\
\text { Squares }\end{array}$} & Df & $\begin{array}{c}\text { Mean } \\
\text { Square }\end{array}$ & F & Sig. \\
\hline $\begin{array}{c}\text { Support for } \\
\text { sustainable tourism } \\
\text { development }\end{array}$ & $\begin{array}{c}\text { Between } \\
\text { Groups }\end{array}$ & 83.128 & 3 & 27.709 & 20.934 & 0.000 \\
\cline { 2 - 7 } & $\begin{array}{c}\text { Within } \\
\text { Groups }\end{array}$ & 746.550 & 564 & 1.324 & & \\
\cline { 2 - 7 } & Total & 829.678 & 567 & & \\
\hline
\end{tabular}

Table 9. ANOVA Analysis of resident attitudes towards sustainable tourism development due to educational level

\begin{tabular}{ccccccc}
\hline Variables & \multicolumn{1}{c}{$\begin{array}{c}\text { Sum of } \\
\text { Squares }\end{array}$} & Df & $\begin{array}{c}\text { Mean } \\
\text { Square }\end{array}$ & F & Sig. \\
\hline $\begin{array}{c}\text { Support for } \\
\text { sustainable tourism } \\
\text { development }\end{array}$ & $\begin{array}{c}\text { Between } \\
\text { Groups }\end{array}$ & 116.495 & 5 & 23.299 & 18.360 & 0.000 \\
\cline { 2 - 6 } & $\begin{array}{c}\text { Within } \\
\text { Groups }\end{array}$ & 713.183 & 562 & 1.269 & & \\
\cline { 2 - 7 } & Total & 829.678 & 567 & & & \\
\end{tabular}

Table 10. ANOVA Analysis of resident attitudes towards sustainable tourism development due to personal income

\begin{tabular}{ccccccc}
\hline Variables & \multicolumn{1}{c}{$\begin{array}{c}\text { Sum of } \\
\text { Squares }\end{array}$} & Df & $\begin{array}{c}\text { Mean } \\
\text { Square }\end{array}$ & F & Sig. \\
\hline $\begin{array}{c}\text { Support for } \\
\text { sustainable tourism } \\
\text { development }\end{array}$ & $\begin{array}{c}\text { Between } \\
\text { Groups }\end{array}$ & 4.211 & 2 & 2.105 & 1.441 & 0.238 \\
\cline { 2 - 7 } & $\begin{array}{c}\text { Within } \\
\text { Groups }\end{array}$ & 825.467 & 565 & 1.461 & & \\
\cline { 2 - 7 } & Total & 829.678 & 567 & & & \\
\hline
\end{tabular}




\section{Discussion and Conclusions}

In light of the results of the study answers questions and test hypotheses has been reached following results; The study results showed that the hypotheses that have been status by the researchers were accepted, including six hypotheses and rejected one hypothesis and by reference to the Table 6 . Results of the study signals for the first hypothesis that there is no statistically significant differences were attributed (99\%) as shown in the table, this shows that the community collaborator with tourists with great satisfaction and is simply also shows that the locals are friendly with tourists and they love to experiment. In relation to the perceived advantages of tourism, the respondents feel that, on balance, the tourism industry is beneficial; and to provide activities not only for residents but also for tourists provided to foster a spirit of understanding and rapprochement between the local community and tourists, and (Brunt \& Courtney, 1999) supported this study.

The study results showed for the second hypothesis that there is no a difference statistically significant was the increase of $(100 \%)$ were accepted hypothesis dramatically and this shows that tourism is the active ingredient for the community in identify on tourists and is considered one of the elements that give them jobs unwanted and tourism is an effective element in increasing the environmental awareness in the region and the results show that the community has the ability to initiatives biggest tourist development. The study also showed other aspects of our lives and the importance of the tourism industry and the services sector will be affected by the direct impact of this factor and also that tourism has implications across the economy, as consistent with (Berrittella et al., 2006). As results of the study showed for the third hypothesis is that there is no statistically significant differences were attributed (99\%) was accepted, this shows through the results that tourism development has provided the city of Aqaba, advanced and prosperous that he was in the area of service delivery or availability. This means that the development of tourism on the right track, but in the other hand, through some of the local community that the city of Aqaba lost its airspace own that is considered the town because of tourism, and this does not mean a decline in the level of development but are added to improve the development plans. Results of the study also showed positive tourists its toll on the environment around them, and also the relationship between the tourists and the environment and consistent with (Farmer et al., 2007).

The study results showed for the hypothesis fourth absence of a difference statistically significant was the increase (95\%) as shown in the table were accepted hypothesis, this means that the development of tourism in the city of Aqaba worked for the ouster of some of the local community to participate in recreational activities and there is a segment of the community domestic tourism do not like the lack of interest in the study indicated that the community against any new tourist facilities (forbidden) attract new categories of tourists for several reasons, including customs and traditions, including religious reasons, and consistent with (Rousseau, 1990). As results of the study signals for the fifth hypothesis that there is no a difference statistically significant was the increase of (96\%) were accepted hypothesis. This means that a certain segment of the community does not benefit from tourism and tourism is considered a negative factor in the increased cost of living and it is often stated that analysis is inappropriate to evaluate small, local events, and that input and output analysis is sufficient for this purpose as shown in the table, and consistent with (Schein, 1968).

The study results showed for the sixth hypothesis is that there is no statistically significant differences were accepted hypothesis was attributed (95\%), which means that the local community has been formed for the friendly that tourism is the first element in the spread of pornography also shows that the community rejects the idea of prostitution and pornography in the city of Aqaba was a very high percentage of rejection. The study pointed out that the local community should consider this phenomenon as unacceptable as shown in the Table 6 , and consistent with (Mules, 1999). The results of the study signals for the seventh hypothesis of the existence of a statistically significant differences were rejected and its percentage (94\%) as shown in the table. However, this study also shows that most respondents do not believe that tourism disturbs local activities or creates more vandalism. It may well be that residents are able to adapt to the inconveniences caused by tourism as was found by Rothman (1978). This shows that tourism does not cause congestion and that the community does not care for is the congestion in the city of Aqaba, also shows that tourism provides a ready market for the community, which means that the development of tourism in the right track (Trumbull, 2001).

As results of the study showed for H8A, H8B, H8C, and H8D that there is a statistically significant difference for sex, age, educational level, and the lack of a statistically significant difference for the level of income. This means that the worker sex affected by tourism development. The results showed that the proportion of the largest response was for the female for tourism development and also the age factor is influenced by tourism development and show that the age of 20 to 30 has the largest share, and for the level of education was mostly carrying bachelor's degree and for 
the level of income, it did not have differences in the results for the local community. The current study recommends that the responsible authorities to intensify tourism awareness among the local community through initiatives, seminars, lectures and various tourist activities; and that the responsible parties to increase environmental awareness among the local community; and cooperation with the private sector operator tours (hotels); and the other to provide special local community jobs; and it has initiated the launch of tourist development for effective school students urging them to keep the tourist property, and activating the role of oversight by the public sector to the private sector about the financial cost of tourist facilities; and the provision of tourist facilities that will preserve the culture of the local community from the public scratching; and involve the community events tourism; and work on the involvement of the private sector operator of tourist facilities in the making of decisions to earn tourist experiences; and subjecting private sector companies of the tourism that will provide job opportunities. In light of the above, the present study recommends future research to conduct a similar field studies on other communities to verify the existence of developmental effects tourism, and conducting descriptive studies, to determine whether there were other dimensions of tourism development impact on the local community, and cultural exchange.

\section{References}

Abbasi, M. S., Elyas, T., \& Shah, F. (2015). Impact of individualism and collectivism over the individual's technology acceptance behaviour: A multi-group analysis between Pakistan and Turkey. Journal of Enterprise Information Management, 28(6), 747-768. https://doi.org/10.1108/JEIM-12-2014-0124

Al Azmi, N., Al-Lozi, M., Al-Zu'bi, Z., Dahiyat, S., \& Masa'deh, R. (2012). Patients Attitudes toward Service Quality and its Impact on their Satisfaction in Physical Therapy in KSA Hospitals. European Journal of Social Sciences, 34(2), 300-314.

Al-Badi, A., Tarhini, A., \& Al-Kaaf, W. (2017). Financial Incentives for Adopting Cloud Computing in Higher Educational Institutions. Asian Social Science, 13(4), 162-174. https://doi.org/10.5539/ass.v13n4p162

Al-Badi, A., Tarhini, A., \& Al-Sawaei, S. (2017). Utilizing Social Media to Encourage Domestic Tourism in Oman. International Journal of Business and Management, 12(4), 84-94. https://doi.org/10.5539/ijbm.v12n4p84

Al-Badi, A. H., \& Al-Qayoudhi, W. S. (2014). Adoption of social networks in business: Study of users and potential users in Oman. The International Business \& Economics Research Journal (Online), 13(2), 401-415.

Al-Dmour, H., Al-Madani, S., Alansari, I., \& Al-Dmour, R. (2016). Factors Affecting the Effectiveness of Cause-Related Marketing Campaign: Moderating Effect of Sponsor-Cause Congruence. International Journal of Marketing Studies, 8(5), 114-127. https://doi.org/10.5539/ijms.v8n5p114

Al-Dmour, R., \& Obeidat, B. (2015). Strategic IT-Business Alignment as Managers' Explorative and Ecploitative Strategies. European Scientific Journal, 11(7), 437-457.

Alenezi, H., Masa'deh, R. Alalwan, A., \& Al-Qirim, N. (2017). Factors Affecting e-Government Adoption in Kuwait: A Qualitative study. Electronic Journal of e-Government, 15(2), 84-102.

Alenezi, H., Tarhini, A., \& Masa'deh, R. (2015). Investigating the Strategic Relationship between Information Quality and E-Government Benefits: A Literature Review. International Review of Social Sciences and Humanities, 9(1), 33-50.

Alkalha, Z., Al-Zu'bi, Z., Al-Dmour, H., \& Alshurideh, M. (2012). Investigating the Effects of Human Resource Policies on Organizational Performance: An Empirical Study on Commercial Banks Operating in Jordan. European Journal of Economics, Finance and Administrative Sciences, 51, 44-64.

Allam, M., \& Elyas, T. (2016). Perceptions of Using Social Media as an ELT Tool among EFL Teachers in the Saudi Context. English Language Teaching, 9(7), 1-9. https://doi.org/10.5539/elt.v9n7p1

Almajali, D., \& Tarhini, A. (2016). Antecedents of ERP Systems Implementation Success: A Study on Jordanian Healthcare Sector. Journal of Enterprise Information Management, 29(4), 549-565.

Al-Qirim, M., Rouibah, K., Serhani, M. A., Yammahi, A. R., \& Yammahi, M. A. (2017). Towards a Personality Understanding of Information Technology Students and their IT Learning in UAE University. Education and Information Technologies, 1-12. https://doi.org/10.1007/s10639-017-9578-1

Al-Qirim, N., Rouibah, K., Serhani, M. A., Yammahi, A. R., \& Yammahi, M. A. (2017). Learning Orientations of IT Higher Education Students in UAE University. Education and Information Technologies, 1-14. https://doi.org/10.1007/s10639-017-9589-y

Al-Qirim N., Tarhini, A., Rouibah, K. (2017). Determinants of Big Data Adoption and Success. In International 
Conference on Communications and Future Internet (ICCFI 2017). Jeju Island, South Korea, 10-13 August.

Alqahtani, M. A., Al-Badi, A. H., \& Mayhew, P. J. (2012). The Enablers and Disablers of E-Commerce: Consumers' Perspectives. The Electronic Journal of Information Systems in Developing Countries, 54(1), 1-25.

Alrowwad, A., Obeidat, B.Y., \& Aqqad, N. (2017). The impact of transformational leadership on organizational performance via the mediating role of corporate social responsibility: A structural equation modeling approach. International Business Research, 10(1), 199-221. https://doi.org/10.5539/ibr.v10n1p199

Alshurideh, M., Masa'deh, R., \& Alkurdi, B. (2012). The Effect of Customer Satisfaction on Customer Retention in the Jordanian Mobile Market: An Empirical Investigation. European Journal of Economics, Finance and Administrative Sciences, 47, 69-78.

Altamony, H., Alshurideh, M., \& Obeidat, B. (2012). Information Systems for Competitive Advantage: Implementation of an Organizational Strategic Management Process. Proceedings of the 18th IBIMA Conference on Innovation and Sustainable Economic Competitive Advantage: From Regional Development to World Economic, Istanbul, Turkey, 9th-10th May.

Altamony, H., Al-Salti, Z., Gharaibeh, A. \& Elyas, T. (2016). The relationship between Change Management Strategy and Successful Enterprise Resource Planning (ERP) Implementations: A Theoretical Perspective. International Journal of Business Management and Economic Research, 7(4), 690-703.

Andereck, K., Valentine, K., Knopf, R., \& Vogt, C. (2005). Residents' Perceptions of Community Tourism Impact. Annals of Tourism Research, 32(4), 1056-1076. https://doi.org/10.1016/j.annals.2005.03.001

Bagozzi, R., \& Yi, Y. (1988). On the Evaluation of Structural Evaluation Models. Journal of the Academy of Marketing Science, 16(1), 74-94. https://doi.org/10.1007/BF02723327

Berrittella, M., Bigano, A., Roson, R., \& Tol, R. (2006). A General Equilibrium Analysis of Climate Change Impacts on Tourism. Journal of Tourism, 27(5), 913-924. https://doi.org/10.1016/j.tourman.2005.05.002

Bisharat, H., Obeidat, B.Y., Alrowwad, A., Tarhini, A., \& Mukattash, I. (2017). The Effect of Human Resource Management Practices on Organizational Commitment in Chain Pharmacies in Jordan. International Journal of Business and Management, 12(1), 50-67. https://doi.org/10.5539/ijbm.v12n1p50

Brunt, P., \& Courtney, P. (1999). Host Perception of Social cultural Impact. Annals of Tourism Research, 27(5), 493-515. https://doi.org/10.1016/S0160-7383(99)00003-1

Choi, H., \& Sirakaya, E. (2005). Measuring Residents' Attitude toward Sustainable Tourism. Journal of Travel Research, 43, 380-394. https://doi.org/10.1177/0047287505274651

Cottrell, S., Vaske, J., \& Roemer, J. (2013). Resident Satisfaction with Sustainable Tourism. Tourism Management Perspectives, (8), 42-48. https://doi.org/10.1016/j.tmp.2013.05.005

Creswell, J. (2009). Research Design: Qualitative, Quantitative, and Mixed Methods Approaches (3rd ed.). Thousand Oaks: Sage Publications.

Crotts, J., \& Holland, A. (2013). Objective Indicators of the Impact of Rural Tourism Development. Journal of Sustainable Tourism, 1(2), 112. https://doi.org/10.1080/09669589309450709

Draper, J., Woosnam, K., \& Norman, W. (2011). Tourism Use History: Exploring a New Framework for Understanding Residents' Attitudes toward Tourism. Journal of Travel Research, 50(1), 64-77.

El-Masri, M., \& Tarhini, A. (2015). A Design Science Approach to Gamify Education: From Games to Platforms. Twenty-Third European Conference on Information Systems (ECIS), Münster, Germany. 26-29 May 2015.

El-Masri, M., \& Tarhini, A. (2017). Factors affecting the adoption of e-learning systems in Qatar and USA: Extending the Unified Theory of Acceptance and Use of Technology 2 (UTAUT2). Educational Technology Research and Development, 65(3), 743-763. https://doi.org/10.1007/s11423-016-9508-8

El-Masri, M., Orozco, J., Tarhini, A., \& Tarhini, T. (2015). The Impact of IS-Business Alignment Practices on Organizational Choice of IS-Business Alignment Strategies. The 19th Pacific Asia Conference on Information Systems (PACIS 2015), Paper 215, Singapore, 6-9 July 2015.

Fariborz, A. (2010). Residents' Attitudes towards Tourism Impacts. Cognizant Communication Corporation, 9, 253-261.

Fedai, L., Daglı, G., Altınay, Z., \& Altınay, F. (2017). The examination of occupational burnout and job satisfaction 
of the physical education teachers. International Journal of Economic Perspectives, 11(1), 12-26.

Farmer, J., Knapp, D., \& Benton, G. (2007). An Elementary School Environmental Education Field Trip: Long Term Effects on Ecological and Environmental Knowledge and Attitude Development. Journal of Environmental Education, 38(3), 33-42. https://doi.org/10.3200/JOEE.38.3.33-42

Field, D. (1986). Community and Natural Resource Development. Jufro Secretariat, 42-53.

Gursoy, D., Jurowski, C., \& Uysal, M. (2002). Resident Attitudes a Structural Modeling Approach. Annals of Tourism Research, 29(1), 97-105.

Hajir, J., Obeidat, B., \& Al-dalahmeh, M. (2015). The Role of Knowledge Management Infrastructure in Enhancing Innovation at Mobile Telecommunication Companies in Jordan. European Journal of Social Sciences, 50(3), 313-330.

Hamoud, M., Akour, M. A., \& Al-Salti, Z. (2016). Developing the Main Knowledge Management Process via Social Media in the IT Organisations: A Conceptual Perspective. International Journal of Business Administration, 7(5), 49-64.

Hassouna, M., Elyas, T., \& Abou Trab, M. S. (2015). Customer Churn in Mobile Markets: A Comparison of Techniques. International Business Research, 8(6), 224-237. https://doi.org/10.5539/ibr.v8n6p224

Hussian, A., Elyas, T., \& Nasseef, O. (2013). Research Paradigms: A Slippery Slope for Fresh Researchers. Life Science Journal, 10(4), 2374-2381.

Hunaiti, Z., Mansour, M., \& Al-Nawafleh, A. (2009). Electronic Commerce Adoption Barriers in Small and Medium-Sized Enterprises (SMEs) in Developing Countries: The Case of Libya. IBIMA Business Review, 2(5), $37-45$.

Kanaan, R., \& Gharibeh, A. (2013). The Impact of Knowledge Sharing Enablers on Knowledge Sharing Capability: An Empirical Study on Jordanian Telecommunication Firms. European Scientific Journal, 9(22), 237-258.

Kateb, M., Swies, R., Obeidat, B., \& Maqableh, M. (2015). An Investigation on the Critical Factors of Information System Implementation in Jordanian Information Technology Companies. European Journal of Business and Management, 7(36), 11-28.

Lai, P., \& Nepal, S. (2006). Local Perspectives of Ecotourism Development in Tawushan Nature Reserve. Taiwan Tourism Management, 27(6), 1117-1129. https://doi.org/10.1016/j.tourman.2005.11.010

Lapp, A. (2008). Attitudes towards Initial Tourism Development in a Community with no Prior Tourism Experience. Journal of Sustainable Tourism, 16(1), 5-22. https://doi.org/10.2167/jost630.0

Latkova, P., \& Vogt, C. (2012). Residents' Attitudes toward Existing and Future Tourism Development in Rural Communities. Journal of Travel Research, 51(1), 50-67. https://doi.org/10.1177/0047287510394193

Lee, T. (2013). Influence Analysis of Community Resident Support for Sustainable Tourism Development. Tourism Management, 34, 37-46. https://doi.org/10.1016/j.tourman.2012.03.007

Mahadeen, B., Al-Dmour, R., \& Obeidat, B. Y. (2016). Examining the effect of the Organization's Internal Control System on Organizational Effectiveness: A Jordanian empirical study. International Journal of Business Administration, 7(6), 22-41. https://doi.org/10.5430/ijba.v7n6p22

Maqableh, M., \& Karajeh, H. (2014a). Job Scheduling for Cloud Computing Using Neural Networks. Communications and Network, 6(3), 191. https://doi.org/10.4236/cn.2014.63021

Maqableh, M., \& Karajeh, H. (2014b). A Theoretical Perspective on the Relationship between Leadership Development, Knowledge Management Capability, and Firm Performance. Asian Social Science, 10(6), 128.

Masa'deh, R. (2012). The Impact of Management Information Systems (MIS) on Quality Assurance (QA): A Case Study in Jordan. International Journal of Information, Business, and Management, 93-110.

Masa'deh, R. (2013). The Impact of Information Technology Infrastructure Flexibility on Firm Performance: An Empirical Study of Jordanian Public Shareholding Firms. Jordan Journal of Business Administration, 204-224.

Masa'deh, R. (2016). The Role of Knowledge Management Infrastructure in Enhancing Job Satisfaction at Aqaba Five Star Hotels in Jordan. Communications and Network, 8(4), 219-240. https://doi.org/10.4236/cn.2016.84021

Masa'deh, R., \& Kuk, G. (2009). Antecedents and Intermediaries between Strategic Alignment and Firm Performance. Conference of the Academy of Management Annual Meeting (AOM), Illinois, Chicago, USA. 
Masa'deh, R., \& Shannak, R. (2012). Intermediary Effects of Knowledge Management Strategy and Learning Orientation on Strategic Alignment and Firm Performance. Research Journal of International Studies, 112-128.

Masa'deh, R., Gharaibeh, A., Maqableh, M., \& Karajeh, H. (2013a). An Empirical Study of Antecedents and Outcomes of Knowledge Sharing Capability in Jordanian Telecommunication Firms: A Structural Equation Modeling Approach. Life Science Journal, 10(4), 2284-2296.

Masa'deh, R., Gharaibeh, A., Tarhini, A., \& Obeidat, O. (2015a). Knowledge Sharing Capability: A Literature Review. In Fourth Scientific \& Research Conference on New Trends in Business, Management and Social Sciences, Istanbul, Turkey, 19-20 September 2015 (pp. 1-16). https://doi.org/10.2139/ssrn.2696924

Masa'deh, R., Hunaiti, Z., \& Bani Yaseen, A. (2008). An Integrative Model Linking IT-Business Strategic Alignment and Firm Performance: The Mediating Role of Pursuing Innovation and Knowledge Management Strategies. Communications of the International Business Information Management Association (IBIMA) Journal, 2(24), 180-187.

Masa'deh, R., Obeidat, B., \& Tarhini, A. (2016). A Jordanian Empirical Study of the Associations among Transformational Leadership, Transactional Leadership, Knowledge Sharing, Job Performance, and Firm Performance: A Structural Equation Modelling Approach. Journal of Management Development, 35(5), 681-705. https://doi.org/10.1108/JMD-09-2015-0134

Masa'deh, R., Obeidat, B., Al-Dmour, R., \& Tarhini, A. (2015b). Knowledge Management Strategies as Intermediary Variables between IT-Business Strategic Alignment and Firm Performance. European Scientific Journal, 11(7), 344-368.

Masa'deh, R., Shannak, R., Maqableh, M., \& Tarhini, A. (2017). The Impact of Knowledge Management on Job Performance in Higher Education: The Case of the University of Jordan. Journal of Enterprise Information Management, 30(2), 244-262. https://doi.org/10.1108/JEIM-09-2015-0087

Masa'deh, R., Tayeh, M., Al-Jarrah, I., \& Tarhini, A. (2015c). Accounting vs. Market-based Measures of Firm Performance Related to Information Technology Investments. International Review of Social Sciences and Humanities, 129-145.

Mash'deh, R., Shannak, R., \& Maqableh, M. (2013b). A Structural Equation Modeling Approach for Determining Antecedents and Outcomes of Students' Attitude toward Mobile Commerce Adoption. Life Science Journal, $10(4), 2321-2333$.

Maynard, G., \& Jones, E. (2007). Community Based Tourism Enterprises Develop. Journal of Sustainable Tourism, 9(4), 644.

Mules, T. (1999). Estimating the Economic Impact of an Event on a local Government area, Region, State or Territory. Bureau of Tourism Research, 28.

Obeidat, B. Y., Hashem, L., Alansari, I., \& Al-Salti, Z. (2016). The Effect of Knowledge Management Uses on Total Quality Management Practices: A Theoretical Perspective. Journal of Management and Strategy, 7(4), 18-29.

Obeidat, B., Al-Suradi, M., \& Tarhini, A. (2016). The Impact of Knowledge Management on Innovation: An Empirical Study on Jordanian Consultancy Firms. Management Research Review, 39(10), 1214-1238.

Obeidat, B., El-Rimawi, S., Maqableh, M., \& Al-Jarrah, I. (2013). Evaluating the Profitability of the Islamic Banks in Jordan. European Journal of Economics, Finance and Administrative Sciences, 56, 27-36.

Obeidat, B., Sweis, R., Zyod, D., \& Alshurideh, M. (2012). The Effect of Perceived Service Quality on Customer Loyalty in Internet Service Providers in Jordan. Journal of Management Research, 4(4), 224-242.

Obeidat, B.Y., Al-Sarayrah, S., Al-Salti, Z., \& Sweis, R. (2016). Cultural Influence on Strategic Human Resource Management Practices: A Jordanian case study. International Business Research, 9(10), 94-114.

Obeidat, B.Y., Tarhini, A., \& Aqqad, N. (2017). The impact of intellectual capital on innovation via the mediating role of knowledge management: A structural equation modeling approach. International Journal of Knowledge Management Studies.

Orozco, J., Tarhini, A., Masa'deh, R., \& Tarhini, T. (2015). A framework of IS/business alignment management practices to improve the design of IT Governance architectures. International Journal of Business and Management, 10(4), 1-12. https://doi.org/10.5539/ijbm.v10n4p1

Pallant, J. (2005). SPSS Survival Manual: A Step Guide to Data Analysis Using SPSS for Windows Version 12. 
Chicago, Illinois: Open University Press.

Puck, L., \& Rats, T. (2000). Tourist and Resident Perceptions of the Physical Impacts of Tourism. Journal of Sustainable Tourism, 8(6), 458-478. https://doi.org/10.1080/09669580008667380

Rothman, R. (1978). Residents and Transients: Community Reaction to Seasonal Visitors. Journal of Travel Research, 16(1), 8-13. https://doi.org/10.1177/004728757801600303

Rousseau, D. (1990). Assessing Organisational Culture. Organizational Climate and Culture, 153-192.

Schein, E. (1968). Organizational Socialization and the Profession of Management. Industrial Management Review, $9,1-15$.

Sekaran, U., \& Bougie, R. (2013). Research Methods for Business: A Skill-Building Approach (6th ed.). New York: Wiley.

Shannak, R., \& Akour, M. (2012). Knowledge Management Strategy Building: Literature Review. European Scientific Journal, 8(15), 143-168.

Shannak, R., Al-Zu'bi, Z., Obeidat, B., Alshurideh, M., \& Altamony, H. (2012a). A Theoretical Perspective on the Relationship between Knowledge Management Systems, Customer Knowledge Management, and Firm Competitive Advantage. European Journal of Social Sciences, 32(4), 520-532.

Shannak, R., Obeidat, B., \& Almajali, D. (2010). Information Technology Investments: A Literature Review. Proceedings of the 14th IBIMA Conference on Global Business Transformation through Innovation and Knowledge Management: An Academic Perspective, Istanbul-Turkey, 23rd-24th June, pp.1356-1368.

Shannak, R., Obeidat, B., \& Masa'deh, R. (2012b). Culture and the Implementation Process of Strategic Decisions in Jordan. Journal of Management Research, 4(4), 257-281. https://doi.org/10.5296/jmr.v4i4.2160

Sirakaya, E., Teye, V., \& Sonmez, S. (2002, August). Understanding Residents' Support for Tourism Development in the Central Region of Ghana. Journal of Travel Research, 41, 57-67.

Tarhini, A., Al-Badi, A., Almajali, M., \& Alrabayaah, S. H. (2017). Factors influencing employees' Intention to use Cloud Computing. Journal of Management \& Strategy, 8(2), 47-62. https://doi.org/10.5430/jms.v8n2p47

Tarhini, A., Elyas, T., Akour, M. A., \& Al-Salti, Z. (2016). Technology, Demographic Characteristics and E-Learning Acceptance: A Conceptual Model Based on Extended Technology Acceptance Model. Higher Education Studies, 6(3), 72-89. https://doi.org/10.5539/hes.v6n3p72

Tarhini, A., El-Masri, M., Ali, M., \& Serrano, A. (2016). Extending the UTAUT model to understand the customers' acceptance and use of internet banking in Lebanon: A structural equation modeling approach. Information Technology and People, 29(4), 830-849. https://doi.org/10.1108/ITP-02-2014-0034

Tarhini, A., Arachchilage, N., \& Abbasi, M. (2015). A Critical Review of Theories and Models of Technology Adoption and Acceptance in Information System Research. International Journal of Technology Diffusion, 6(4), 58-77. https://doi.org/10.4018/IJTD.2015100104

Tarhini, A., Mgbemena, C., AbouTrab, M.S., \& Masa'deh, R. (2015). User Adoption of Online Banking in Nigeria: A Qualitative study. Journal of Internet Banking and Commerce, 20(3), 1-8.

Tarhini, A., Mohammed, A., \& Maqableh, M. (2016). Modeling Factors Affecting Student's Usage Behaviour of E-Learning Systems in Lebanon. International Journal of Business and Management, 11(2), 299-314.

Tosun, C. (2000). Limits to Community Participation in the Tourism Development Process in Developing Countries. Tourism Management, 21(6), 613-633. https://doi.org/10.1016/S0261-5177(00)00009-1

Trumbull, C. (2001). Prostitution and Sex Tourism. Journal of Tourism Management, 17(1), 368-370.

Vratskikh, I., Al-Lozi, M., \& Maqableh, M. (2016). The Impact of Emotional Intelligence on Job Performance via the Mediating Role of Job Satisfaction. International Journal of Business and Management, 69-91.

Wang, Y., \& Pfister, P. (2008). Residents' Attitudes toward Tourism and Perceived Personal Benefits in a Rural Community. Journal of Travel Research, 47, 84-93. https://doi.org/10.1177/0047287507312402

Wanko, D., \& Stewart, W. (2002). Structural Equation Model of Residents' Attitudes for Tourism Development. Tourism Management, 521-530.

Zhang, J., Inbakaran, R., \& Jackson, M. (2006). Understanding Community Attitudes towards Tourism and Host-Guest. Tourism Geographies, 182-204. https://doi.org/10.1080/14616680600585455 